\title{
RESSO: A SOCIAL MEDIA NETWORK FOR LUXURY RETAIL
}

\author{
by \\ Asma Arslan \\ Bachelor of Communication Design (BDES) \\ National College of Arts, Lahore, Pakistan, 2009.
}

MRP presented to Ryerson University

in partial fulfillment of the

requirements for the degree of

Master of Digital Media

In the Program of Digital Media

Toronto, Ontario, Canada, 2017

(C)Asma Arslan 2017 


\section{AUTHOR'S DECLARATION FOR ELECTRONIC SUBMISSION OF MRP}

I hereby declare that I am the sole author of this MRP. This is a true copy of the MRP, including any required final revisions.

I authorize Ryerson University to lend this MRP to other institutions or individuals for the purpose of scholarly research

I further authorize Ryerson University to reproduce this MRP by photocopying or by other means, in total or in part, at the request of other institutions or individuals for the purpose of scholarly research.

I understand that my MRP may be made electronically available to the public. 


\title{
RESSO: A SOCIAL MEDIA NETWORK FOR LUXURY RETAIL
}

\author{
Master of Digital Media, 2017
}

Asma Arslan

Master of Digital Media, Ryerson University

\begin{abstract}
This Major Research Project investigates the role of social media to fill the gap created in online and offline dynamics of Luxury Industry over the recent years. This gap is evident in the fact that $75 \%$ research about a purchase is done online but online sales bring are only a mere $6 \%$. Psychological study of luxury brand consumers informs the aim of luxury brands to mainly deliver status elevation, social stratification and internal satisfaction. Resso is a project inspired by the psychological objectives of luxury consumers and online consumers decision journey referred to as CDJ. Resso is an online hybrid luxury market place which is a highly interactive social media network where users shop luxury goods. They also receive luxury client services, offers, access to latest reviews and YouTube influencers linked to each product. Users make real connections with each other and an option to give and track charity on one digital platform. The paper will discuss theories of luxury brand management, present digital scenario, the design structure and affordances of the project Resso.
\end{abstract}




\section{Dedication}

Dedicated to my parents, siblings and my husband Arslan Khattana. 


\section{Table of Contents}

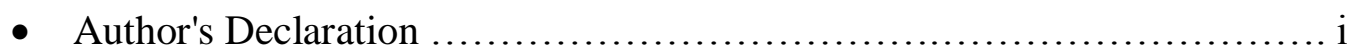

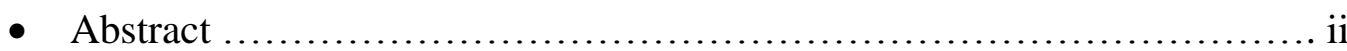

• Dedication........................................................ ii

- Table of Contents................................................. iv

• Introduction........................................................ 1

- Related literature and Projects................................... 2

○ Consumer Decision Journey ............................... 2

○ The Luxury Dream...................................... 4

○ High street fashion vs Premium vs Luxury....................... 4

○ Psychology of Luxury Consumers.............................. 5

○ The World's Obsession with Social Media......................... 7

○ Selective Retailers........................................ 9

• Thesis............................................................... 11

- Design Affordances................................................. 11

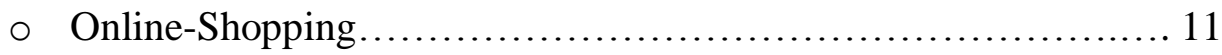

○ Social Networking...................................... 12

○ Registering Process to Social Network....................... 12

○ News Feed................................................. 13

○ Personal Profile............................................ 13

○ Trackable Donation Model......................................... 14

- Partnering with brands and selective retailers ........................ 14

- Client Database ................................................... 15

- Conclusion....................................................... 15

$\quad$ References...................................................... 16 


\section{Resso: A Social Media Network for Luxury Retail}

\section{Introduction}

Despite the world's economic crisis, wars and inflation, the luxury industry has not been effected. The global industry for personal luxury goods presently has a $\$ 21$ billion online market which could grow up to a $\$ 104$ billion by 2025 if accurate measures are taken. Online reviews and digital influences are responsible for $75 \%$ of sales in the industry including the sales in stores. This could rise up to a $100 \%$ digitally inspired luxury retail by 2025 . On the other hand, a mere $6 \%$ of the entire luxury goods industry comes from online transactions, clearly people research online and purchase offline. It has also been found that nearly all luxury consumers have at least one smartphone, the figure is 95 percent around the world and in some countries 100 percent luxury consumers own smart phones (Remy, Catena, Servoingt, 2015). This paper discusses the connection between the socially and technologically active luxury consumer's psychology, dynamics of luxury industry and the current digital consumer's decision journey.

According to Webster's Dictionary definition of 'luxury' is defined as "an expensive rarity". Another definition is "Exclusivity, premium prices, image and status which combine to make products more desirable for reasons other than functions" (Kapferer,2015). Before forming a solution, the following paper has probed into the reasons other than function part mentioned in the above definition, examined relevant literature and industry trends to find a strategy and design the solution. 


\section{Related literature and Projects}

\section{Consumer Decision Journey}

Purchasing patterns of consumers have changed majorly since the boom of ecommerce and the internet. The Consumer Decision Journey (CDJ) model is a proven retail and marketing model after 20,000 consumers across five industries in three continents were studied by Mckinsey and Company (Court 2009).

Earlier the decision process of consumers was the Purchase Funnel which is composed of the following steps: awareness, familiarity, consideration, purchase and loyalty. It started with lots of options and narrowed down to a single purchase which was a controlled process by the brand. However, since information channels have opened up and direct communication is possible with consumers, the buying process is in control of the consumer now. Due to vast knowledge over the internet, bombardment with one sided advertising messages has become outdated. Thus, Purchase Funnel is an obsolete less-efficient linear model replaced by CDJ (Eledman,2010) (Court, 2009).

Customer Decision Journey is an intelligent purchase model that emphasises the customers and their free will to purchase after learning, reviewing, discussing and eyeing the product online for as long as they want.

The stages of consumer decision journey are following:

1. Consideration

2. Trigger

3. Active Evaluation 


\section{Moment of Purchase}

5. Loyalty loop: Enjoy-Advocate-Bond

Consideration which is ongoing exposure such as advertising or visual stimuli for example window displays while walking through malls or admiring a friend's handbag. Trigger (when you decide to buy). Active Evaluation stage where the number of brands to be considered increases, some brands are added some are subtracted. It is this stage when the consumer is intent on purchasing and is actively researching, discussing and mining the internet for knowledge about the product. After a long internet research comes Moment of Purchase or how Kapferer (2015) describes it as the Purchase Ceremony which is a crucial stage usually done in the store. The service, the environment, the sales person, the physical product and packaging all become decision factors for the purchase. If client is not amused by the store experience, the sale can be easily lost and the client can turn away. The final stage is the Loyalty Loop comprised of Enjoy-AdvocateBond with purchase. Consumers also sometimes research their purchase after they buy in order to learn more about what they are using. In the Loyalty Loop, there are active and passive product loyalists; active loyalists are the ones who regularly buy and advocate, basically your walking talking marketing machines. While passive loyalists believe that the next time they will be open towards their present purchase but will study other options all over again. A structured and facilitated Loyalty Loop reassures the purchase, brands can nurture articles, reviews, communities online and post purchase services as well (Edelman,2010).

In order to develop solutions, there is a rising need to understand touch points that influence this new digital consumer during CDJ stages. It is a combination of company driven and consumer driven touch points. The journey starts with advertising which is company driven. Consumer takes control during active Evaluation, Purchase and Loyalty Loop. It is important to 
somehow intervene and strategize when consumer is reaching out to investigate and exhibit a product through word of mouth, online reviews, YouTube videos and searches. Companies should make it easy for communities to talk openly about their products and also be available to answer inquiries and satisfy consumers online.

\section{The Luxury Dream}

A luxury purchase is a dream achieved and a way of broadcasting your success. Luxury Brand Management specialist Prof. Jean-Noël Kapferer (2015) ascertains that Luxury Brands sell dreams. The psychology of luxury consumers shows core reasons behind purchases being, personal reward, elevation of status and social stratification (Kapferer, 2015). Luxury brands teach its customers the ways of the stylish and wealthy, classifying people who want to identify themselves as elite.

On the surface level, rarity, exclusivity (Kapferer,2015), design, craftsmanship, brand's legacy and quality of the product are decision factors for luxury customers according to research.

\section{High street fashion vs Premium vs Luxury}

There are ample new classifications of personal consumer goods, such mass-prestige, prestige, premium, fast fashion, high street etc. The core difference in product is that Luxury is a long-term purchase that does not go out of fashion but turns into an artifact with time.

Sustainability is meant to be an important aspect of luxury industry as their goods are highly durable and are of the finest quality. Luxury products sources are also trackable and fair, none of these factors are used as their adverting hooks. Instead of buying fifteen different products, luxury consumer is meant to buy one, durable, long lasting product which is like a dream achieved (Kapferer, 2015). On the other hand, high street fashion is disposable, less durable, 
often ambiguously sourced, mass produced and clearly the opposite to luxury. However, people often miss the difference between premium brands and luxury brands. Premium brands offer rational, good quality purchases that justify their prices to customers. For example, Lancôme being a premium brand that pleases its consumers with a gift with purchase. It is a line that is continuously striving to advertise about better ingredients and creating special offers. Consumer shows progress by purchasing premium brands but it is not the dream come true like luxury. Luxury is not the next step up from premium. However, luxury is a certain hedonism hidden in ultimate pleasure of indulging in your dream purchase and making a social statement e.g. a new Ferrari or Chanel handbag owner enjoying eminence amongst people who acknowledge the purchase.

Customers who purchase luxury goods are more likely to connect with others who buy luxury goods as well. It gives them a chance to exhibit or review their purchases amongst each other. Thus, Premium or high street fashion buyers are of less interest to them socially and for gaining product knowledge.

\section{Psychology of Luxury Consumers}

\section{Self-reward and Hedonism.}

Luxury purchases are made to reward oneself as a fruit of persistent hard work (Kapferer, 2015). For example, female consumers usually reward themselves after reaching their target weight with a luxury purchase. 


\section{Internal Satisfaction}

Another possibility is permeation of guilt during the luxury shopping experience. Owning a $5000 \$$ handbag can also effect the consumer when they see someone else's financial suffering.

Sharing for a genuine cause brings internal satisfaction to most individuals. Donating something small while buying an expensive product for their leisure brings particular inner satisfaction to luxury consumers. It is of key importance that the charity cause should be genuine and reach the rightly deserving individual instead of getting lost in the process. For example, with every purchase, the luxury shoe brand Toms started off by donating one pair of shoes to a remote community where people cannot afford shoes for their children. This has become the prime attraction of buying Toms and a massive trend setting stage in the industry.

\section{Social Stratification}

Out of the tree main psychological objectives the most important one behind luxury purchase is Social: Elevation of Status and Social Stratification

Before eighteenth-century Kings, Priests and Nobles were differentiated from the masses by the use of premium quality products like silks and jewels. Later, once this class system and the divide was demolished, there still remained a need for people to belong to some kind of strata. Now that democracy and equality play important roles in society, there remains an unspoken need to set a code for social hierarchy, luxury Industry fills that need (Kapferer 2015). The modern world depicts celebrities as royalty of the media who consume luxury brands and world aspires to do the same. These could be your favorite film actors, wealthy socialites or YouTube influencers. Often the trend of using famous Hollywood celebrities as advertisement faces of luxury brands has worked due to the same reason (Elberse, 2013). Consumers are also 
particularly interested to see what their favorite celebrities are wearing at events, personal life or in their YouTube videos (if they are YouTube influencers). The Princess of Wales, Lady Diana used to carry a particular Christian Dior handbag, the bag quickly became a craze for people around the world because Lady Diana owned one. Ultimately, Dior had to bring out an entire collection of that specific bag in various sizes and colors and changed its name to Lady Dior handbag collection. This handbag has turned into the signature Dior, ever popular handbag.

Besides following celebrities, social imitation amongst peers also plays a major role in the psychology of luxury consumers, they are always surveilling others for their brands, products, place of buying and their opinions. Luxury consumers are most often subconsciously comparing themselves to each other. There is a tone of competition and mutual inspiration in their purchasing behavior. Showing off the luxury purchase in a subtle, subconscious way is conforming to the standards of their social strata, becoming modern-day luxury brand wearing elite. It is of as much importance for them to be around people who recognize it.

\section{The World's Obsession with Social Media}

Research informs that luxury consumers actively use social media. $80 \%$ use social media on a monthly basis, whether it's Instagram, We-Chat, Facebook or Twitter. Half are weekly users and more than $25 \%$ are daily social media users. They are also highly active users. Two-thirds generate social media content such as photographs, videos, product reviews or repostings of content created by others at least once a month, while 15\% do it daily (Remy, Catena, Servoingt, 2015). For luxury consumer, what could be a better time for graceful exhibition of their luxury goods, than the age of social media. Social media is unfortunately underutilized by luxury brand strategists, limited to running social pages and editorial websites. 


\section{Exclusive networking vs Facebook}

A person who wears a Rolex would always like to network with others who wear it, if not at least others who acknowledge it. Online nobody can see if someone is wearing a Rolex unless they post pictures like the rich kids on Instagram. Networks like Instagram where you post pictures of your life including what you are buying for yourself are limited to following and fandom and doesn't give you seamless real connections. These large generic networks are overloaded with all sorts of irrelevant people and irrelevant information for luxury consumers. Affluent consumers have minimized the use of Facebook due to concerns about not being inspired because they are not connecting with their own kind, privacy and information overload (Jones, 2008) but they also deeply appreciate the advantages of social-networking aspect of Facebook. Earlier they would only get the opportunity at country clubs or at annual international meetings, but now they can instantaneously connect to like-minded people globally if they find the right digital place (Jones, Pedraza, 2016).

Luxury customers being one percent of the world's population would always feel the need to network and build extended, real and secure relationships amongst each other in order to avoid alienation. Exclusive digital networks like Asmallworld, Diamondlounge and Squa.re (Ruiz, 2008) provide a vetted, trusted and intimate setting that allows affluent consumers to be open and post spontaneously about themselves and their activities (Ruiz, 2008). Satisfying their requirement for being a part of elite, thus, socially stratified. 


\section{Selective Retailers}

Selective retailers are department stores that house a vast variety of luxury brands and products. The role model of selective retailers is Harrods in London UK, which follows Kapferer's (2015) luxury strategy to its fullest. The world's elite society shops at Harrods for the tactile purchasing experience and aspirers follow one another. Since Harrods has elite store traffic and a great place for meeting or bumping into the who is who, it is universally considered a luxury icon and a symbol of elevated status to be associated with it. Harrods has a cultural legacy and a story, a concept that luxury brands thrive on. Other major luxury selective retailing stores around the world are Saks Fifth Avenue, Holt Renfrew (Canada), Neiman Marcus, Bloomingdales, Selfridges, Nordstorms etc. However, sometimes the practices of selective retailing clash with luxury brand strategies and this ends up turning clients away at the point of purchase in the Consumer Decision Journey. Stores and selective retailers have turned into points of sale instead of being relationship building centres (Jones, Pedraza,2016). The new design of stores aesthetically and digitally has to make clients feel special and inspires them to buy. In the recent years some selective retailers are becoming exceedingly aggressive in their sales strategies in order to meet targets without realizing that luxury brand values are to never push clients to purchase.

\section{Flawed Client Service Systems}

Some brands at selective retailing stores make client files for client management purposes and juice out the minimal client information their files entail. Instead of building client relationship these files fetch the purpose of making sales targets for the sales representative. They have personal information about clients, look flimsy, are too easy to misplace and 
information is usually not updated as it is supposed to be done every time the client walks in (personal communication, 2017). At stores which work with pre-orders for their events, their client's personal information (such as credit cards details for preorders) is often left on these barely secure files with a risk of being compromised. Their poor management of information makes the clients privacy at risk (personal communication, 2017).

\section{Clienteling}

Clienteling is the practice of making luxury customers feel special and building relationships. Customized personalized services while you educate them on the brand and maintain contact. These luxury experiences often turn clients into marketing machines of your brand. Clientele pulls consistent business through the long-term relationships developed with the customer even if it does not give instant gains.

According to a 2016 research conducted by Walpole (2016) in UK, online personalization is amongst the top three the forthcoming successful trends in luxury business. It is as a tool of luxury's digital future, some options of online personalization are notifications, reminders, personalized service oriented communication instead of mass emails etc.

Current popular online luxury retailers are Net a Porter, Sephora, Nordstrom's, Saks Fifth Avenue. However, none of these have an online clientele strategy with focus on personalization. Present online luxury retailers also are not equipped with tools for social networking amongst their customers to create communities. 


\section{Thesis}

"Social stratification, imitation and networking can fill the gap between online and offline luxury shopping experience and expand online luxury sales.”

If executed intelligently, shopping for luxury goods in a social media environment could be the recipe for luxury ecommerce success. In the recent years, being physically present in the store is not as important anymore as it was a decade ago for luxury customers (Dauriz, Remy, and Sandri, 2014). Resso model is an online luxury goods market place; Combination of logistics, reviews, consumer focused elements of an online store such as Amazon with some elements of a social media network such as Facebook. The social elements are Networking, newsfeed, communities, notifications and display of posts exclusively for luxury consumers. This hybrid social media market place is designed in the form of a website and a phone app.

\section{Design Affordances}

\section{Online-Shopping}

The network has an online shopping approach of any selective retailer such as Hudson's Bay or Sephora online. A selective range of luxury brands and products are available for online shopping. However, in the initial stages personal luxury goods such as beauty products, handbags, shoes and belts would be available in order to manage better. Each brand can help run their sections with the help of constant collaboration between the luxury brands and Resso. Brands can facilitate long term relationships by offering complimentary entities such as services, spa experiences, gifts, tokens of appreciation or free handbag cleaning. Besides having general events, the algorithms note regular transactions of users and help create a best possible package with complimentary entities for their purchases. 


\section{Social Networking}

A luxury brand enthusiast would always want a profile on the website of a prestigious platform for example Harrods, to connect with the who is who or to show off a purchase or just watch silently. Users can post pictures and videos like Instagram or Facebook. Make connections based on profiles or interests or such as liking the same bag etc. Consumers can enjoy purchase announcements of their acquaintances shopping and honest first hand casual reviews from their contacts as well. Like all other social networking sites, it also has a message inbox and chat group option.

Social network for the purpose of retail is a great tool to increase user engagement and approaching users at all stages of the consumer decision journey. Specially during the Loyalty Loop of the CDJ which was often left uncurated before. A place which gives people opportunity to become potential luxury celebrities by sharing honest reviews and their journey. Resso brings birds of the same feather together, to appreciate and exhibit luxury ecommerce experience (Kapferer, 2012).

\section{Registering Process to Social Network}

Starting a discussion with an advertising campaign on relevant touch points such as luxury magazines like Harper's Bazaar, Vogue, GQ or Elle. Initially, an investment will be required to attract customers with special offers and have celebrities join Resso. For example, a supposed minimum of a $1000 \$$ purchase at Resso website gives access to consumers to be a part of Resso's social network. Customers may receive a Resso login card along with their first delivery. They can scan this card on the phone with the help of the NFC technology on the card. Near Field Communication (NFC) is a prevalent technology which has receptor in your phone and 
the NFC chip operates in close proximity with the phone. The Resso consumer can connect to their profile on Resso social network and can further build it, personalize it and start socializing.

\section{News Feed}

News feed controlled by Resso contains blogs, articles, customer reviews and access to YouTube influencer videos via APIs from YouTube. Most news feed is generated regarding the products you are interested in by the use of shopping/search history, my crushes and algorithms. It also displays announcements to celebrate the recent purchases of your social connections or celebrities.

\section{Personal Profile}

A page with a profile photograph and relevant information about user like that on Facebook. This user's profile page is preferred to have open information shared with the network in order to have convenient searchability and approachability. Users can publish pictures, thoughts, products and purchases on their profile with a choice in privacy settings. Following are the main sections on the profile page.

- My Posts is where users can post information such as pictures, videos, sharing location while in luxury store, events about their lives and so on.

- My Purchases and Reviews is another important section on the profile that publishes first hand reviews and confirmation of products purchased by the user. This can prove helpful for open communication in order to make another user's decision easy. Opening dialog will also give brands a challenge to perform their best.

- My Crushes is a place where the users add all their wish list products, this can be useful for the Active Evaluation stage of the Consumer Decision Journey (Edelman, 2010). As luxury sales are time consuming and a slow process, My Crushes is a valuable space to 
keep reminding the client about their forth coming purchase and sharing information about it. The algorithms constantly mine information, videos and news about your crushes and help to keep posting it for you on the side of this page.

\section{Trackable Donations Model}

Thanks to Toms shoes, rise of luxury with a conscience concept has set stage for charitable action for the industry. The option of donating for a genuine cause offered to Resso customers at checkout hones that concept. In an extremely transparent process, customer's money spent on charity will be tracked for the customer until it reaches its final destination. Resso plans to partner with non-for-profit humanitarian organizations that can electronically give account for every penny donated to them. If a customer is purchasing worth $10,000 \$$, donating $50 \$$ will bring them extended internal satisfaction furthering their joy towards achieving their luxury dream (Kapferer, 2015).

\section{Partnering with brands and selective retailers.}

A part of Resso's internal model will work like an agency. Brands will be actively participating on most levels of the platform by employing a shared resource within Resso as an account manager for the brand's social communities, crafting complimentary entities and communicating with consumers, stores and sales personal. This account manager will help create Resso's online and brands offline point of service mergers. For example, by offering Dior spa services to a client when they purchase Dior skincare from Resso. With the rise of Artificial Intelligence, the job of this account manager can be supported with the use of algorithms. 


\section{Client Database}

Personalization and customization are key important tools of luxury industry in the digital age (Walpole, 2016). With a combination of algorithms and data scientists working together at the back end, Resso's model gives the opportunity to extract valuable data. This data may prove useful for online clienteling according to customer segments, demographics, interests, tastes, likes, budgets and purchase history. Instead of sending spam emails, there can be real relationships between the Resso user and the customer service staff via email or phone. Personalized online clienteling with the help of a good data strategy can help position Resso as a genuinely consumer oriented model.

\section{Conclusion}

After establishing Resso in North America, the future plan is to dive into global luxury markets. Resso can make different logistics systems and expand to various countries such as China, Europe and Middle East. The most sensitive language translators are now easily available and can be imbedded according to the language of each region. Resso shall be adapting a globally inclusive approach, giving an open opportunity to luxury consumers to connect with each other regardless of their boundaries around the world. Beside personal luxury goods, adding categories such as experiential luxury, wine, spirits, home interior design and apparel is also on the agenda once the project matures.

A social media marketplace may prove to be a revolution in the online luxury retail world. It addresses core concerns for the industry's ecommerce gap. Serving as a social status elevator and networking tool to make real connections which is the core drive behind luxury purchases. 


\section{References}

Court, D., Elzinga, D., Mulder, S., \& Vetvik, O. (2009). The consumer decision journey. Retrieved from McKinsey \& Co: http://www.mckinsey.com/business-functions/marketing-andsales/our-insights/the-consumer-decision-journey

Dauriz, L., Remy, N., \& Sandri, N. (2014). Luxury shopping in the digital age. McKinsey \& Company. Paris, Munich, Milan: McKinsey \& Company.

Edelman, D. (2010, 12). Branding in the Digital Age. HBR's 10 must reads On Strategic Marketing, 15-28. Boston,Massachusetts: Harved business Review Press

Elberse, A. (2013). Blockbusters: Hit-Making, Risk-Taking, and the Big Business of Entertainment. United States: Henry Holt and Co.

Jones, S., \& Pedraza, M. (2016, March 02). Retail store system is broken: Luxury Institute. Retrieved from http://luxuryinstitute.com: http://luxuryinstitute.com/blog/?cat=55

Kapferer, J.-N. (2015). Kapferer on Luxury : How Luxury Brands Can Grow Yet Remain Rare. Kogan Page.

Kapferer, J.-N. (2010, 04 19). brand-management.usi. Retrieved from THE LUXURY STRATEGY Break the rules of marketing to build luxury brands: http://www.brandmanagement.usi.ch/Keynotes/kapferer-Luxury.pdf

Remy, N., Catena, M., \& Servoingt, B. D. (2015). Digital inside: Get wired for the ultimate luxury experience. Apparel, Fashion \& Luxury Group. Milan, Paris: McKinsey \& Company.

Rourke, B. (2017, 05 12). Dior Counter Manager. Personal Communication. (A. Arslan, Interviewer)

Ruiz, N. (2008, 5 2). Five Social Networking Sites Of The Wealthy. Retrieved from Forbes: https://www.forbes.com/2008/05/02/social-networks-vip-tech-personalcx_nr_0502style.html

Walpole. (2016). How to Attract the Luxury Consumer in 2020. UK: WSGN . 